\title{
Development and Quality Evaluation of Ready to Bake Vegetarian Cake Mix
}

\author{
R. M. N. A. Wijewardana ${ }^{1^{*}}$, S. B. Nawarathne ${ }^{2}$ and I. Wickramasinghe ${ }^{2}$ \\ Received : $08^{\text {th }}$ July 2015 / Accepted : $25^{\text {th }}$ Septeber 2015
}

\begin{abstract}
Three different formulas of ready to bake vegetarian cake mixes were prepared and quality and storability were analyzed. Proximate composition, beta carotene, colour (Lightness, redness and yellowness) of flour mix in terms of $L^{*}, a^{*}$ and $b^{*}$ and total plate count were determined $(n=3)$. The results were analyzed by completely randomized design using ANOVA by SAS statistical package and mean separation was done by using Least Significant Difference (LSD) at $\alpha=0.05$. The initial moisture content of cake mix 1, 2 and 3 were $5.23 \%, 6.41 \%$ and $5.61 \%$ and it was increased up to $5.63 \%, 6.79 \%$ and $5.84 \%$ respectively. High percentage of fat was recorded in Mix-1 (T1) and the least in Mix-3 (T3) and least in Mix 2 (T2). All three mixes were not exceeded the safe limit of water activity for microorganisms $\left(a_{w}=0.6\right)$ and resulted low microbial load $\left(1.8^{*} 10^{3}\right)$. Addition of pumpkin flour and bale powder proportionately increased the yellowness of flour mixes and the $L^{*}, a^{*}$ and $b^{*}$ colour values were significantly $(p<0.05)$. The prepared cakes were analyzed for physico-chemical properties and consumer acceptability using 5 point Hedonic scale. Mix- 3 (T3) that containing wheat flour, rice flour, bael powder and pumpkin flour 10\%, 17\%, 3\%, and 15\% respectively was identified as the most suitable combination of ready to bake vegetarian cake mix (dry mix) and could be stored for 90 days without noticeable quality deterioration. According to the results obtained, the vegetarian ready to bake cake mix 3 was identified as the most preferable formula with the highest consumer acceptability.
\end{abstract}

Keywords: Pumpkin flour, Dehydration, ready to bake, vegetarian cake mix, bael

\section{INTRODUCTION}

In Sri Lanka, postharvest losses in fruits and vegetables estimated to be $30-40 \%$, due to climatic and seasonal variations. Sri Lanka is an agricultural country because majority of rural population is still engaged in agricultural sector. The vegetable sub-sector is considered as the second most important sub-sector. Vidanapathirana, 2008 reported that vegetable are produced on a year round basis and a large number of farmers are involved in the production process in Sri Lanka. The fruit can be stored up to 6 months hence it can play an important role providing nutrition to the consumers even the dry spells (Nisha and Veerarangavathatham, 2014). Pumpkin (Cucurbita moschata: Cucurbitaceae) is a known vegetable in many tropical and tropical countries due to high

content of vitamin A, the color of pumpkin pulp is orange. The main nutrients are lutein and both alpha and beta carotene, the latter of which generates vitamin A in human body (Ahamad et al., 2011). Carotenoids are the primary source of vitamin A for most of the people in the developing countries (Boileau et al., 1999) where vitamin A deficiency is still common ( Chakravarty,2000)

Pumpkin takes a prominent place among other vegetables because; it's high productivity, nutritional value, good storability, and long period of availability and better transport qualities. Fresh pumpkin is very susceptible for microbial spoilage after opening even at refrigerator conditions. But it has a possibility 
to use as an ingredient for food preparation because it is rich in carotenoids, minerals, vitamins pectin and dietary fiber. Pumpkin flour is the most convenient way of preservation because of its stability. The flour as an ingredient for food application due to desirable flavor and attractive deep yellow color profiles. It has been reported that utilization of pumpkin flour as a supplement for bakery products snacks, cakes, cookies, bread etc. (Ptitchkina et al., 1998).

In recent years, the development and evolution of functional foods targeting the consumer demand has been increased considerably. Further, pumpkin is rich in nutrients and use as cooked vegetable and as a thickening agent (Usha et al., 2010). The study was conducted to develop a ready to bake vegetarian cake mixture by replacing wheat flour with dry flour of rice, pumpkin and bael.

\section{METHODS AND MATERIALS}

\section{Sample preparation}

Pumpkins (Cucurbita maxima) were harvested from a farmer field at North Central province in Sri Lanka at the proper maturity stage. Ash strips were appeared on the fruit surface. The diseased and damaged fruits were rejected. Bael (Aegle marmelos) fruit powder was prepared by drying at $50^{\circ} \mathrm{C}$ in vacuum drier (SELECTA, Spain) for $12 \mathrm{hrs}$ and the pulp followed by grinding and sifted to get fine partials less than $150 \mu \mathrm{m}$. Soursop (Annona muricata) and pumpkins (Cucurbita maxima) prepared for dehydration by dipping in $1.5 \mathrm{~g} / 1$ sodium metabisuphyte solution after slicing followed by blanching for 3 minutes in hot water $\left(60^{\circ} \mathrm{C}\right)$ and dried in vacuum drier at $50^{\circ} \mathrm{C}$. Powder was prepared by drying followed by grinding and particle size is $150 \mu \mathrm{m}$. Ginger powder was prepared by fresh, clean, washed rhizomes drying in vacuum drier at $50^{\circ} \mathrm{C}$ and sifted to get fine particles $(150 \mu \mathrm{m})$. Rice flour was sifted and get particles $(200 \mu \mathrm{m})$. Wheat flour, baking powder, vanilla, sugar, non fat milk powder, glecerol monostarate (mould inhibiter) was used as other ingredients, and purchased from the local market.

\section{Product formulation: Ready to bake vegetarian cake mix}

Three different cake mixes (treatments) were prepared by mixing wheat flour, rice flour, dehydrated bale (Aegle marmelos) powder, Sour sop (Annona muricata) powder and pumpkin powder in different proportions. Cakes were prepared by adding $40 \mathrm{ml}$ of refined soya oil to $250 \mathrm{~g}$ of prepared cake mixture and mixed well by adding $120 \mathrm{ml}$ of water in a stainless steel bowl till smooth batter was formed . The batter was then placed in a paper lined tray and baked in a pre-heated oven at $180{ }^{\circ} \mathrm{C}$ for 45 minutes. The cakes prepared from three formulations were tested as shown in Table 01 .

\section{Determination of physicochemical parameters}

Moisture, fat, protein, total ash, fibre, $\beta$-Carotene, $a_{w}$, colour and microbial quality (Total Plate Count) were determined in cake mixtures.

Moisture content: Moisture content was determined using the method described in AOAC, 2005. $10 \mathrm{~g}$ sample was dried in hot air oven at $105^{\circ} \mathrm{C} \pm 1^{\circ} \mathrm{C}$ in pre-weight dishes till constant weight. The dried sample was transferred to desiccators with dishes and cooled to room temperature. The dish was then weighed and moisture content in per cent was calculated from loss of weight.

Ash: $5 \mathrm{~g}$ of ground sample was taken in a preweighed silica crucible and charred over the heater to make it smoke free. The crucible with the sample was ignited at $600^{\circ} \mathrm{C}$ for 3 hours in a muffle furnace. When muffle furnace was slightly cooled, the crucible with ash was taken out, kept in desiccators to cool and constant weight was taken. The difference between the weight of the silica crucible as empty and with ash was the amount of total ash. The percent ash was calculated (AOAC, 2005). 
Table 01: Different formulas of ready to bake vegetarian cake mix

\begin{tabular}{lccc}
\hline \multirow{2}{*}{\multicolumn{1}{c}{ Ingredients }} & \multicolumn{3}{c}{ Composition (\%) } \\
\cline { 2 - 4 } & $\mathrm{T} 1$ & $\mathrm{~T} 2$ & $\mathrm{~T} 3$ \\
\hline Wheat flour & 8 & 10 & 10 \\
Rice flour & 20 & 12 & 17 \\
Sour sop flour & 2 & 10 & - \\
Pumpkin flour & 15 & 13 & 15 \\
Bael powder & - & - & 03 \\
Baking powder & 5.6 & 5.6 & 5.6 \\
Vanilla powder & 0.2 & 0.2 & 0.2 \\
Sugar & 40 & 40 & 40 \\
Milk powder & 8 & 8 & 8 \\
GMS & 0.8 & 0.8 & 0.8 \\
Ginger powder & 0.4 & 0.4 & 0.4 \\
\hline
\end{tabular}

GMS- Glycerol monostarate

Crude fat and crude protein: Crude fat and crude protein were determined according to the method given in AOAC (2005).

Crude fiber: Two gram of sample was put into $250 \mathrm{~mL}$ conical flask and $1.25 \%$ Sulfuric acid solution was added. The sample was heated about $30 \mathrm{~min}$ and was filtered using vacuum filter and washed until traces of acid was undetected using $\mathrm{pH}$ paper. The Whatman paper 5B which pore size 125 micrometer was placed in the Buchner flask. After that the acid extracted was transferred into $250 \mathrm{~mL}$ conical flask and $1.25 \% \mathrm{NaOH}$ solution was added. Digest the contents for half an hour, filter and wash free of alkali using hot distilled water. The residue was transferred to crucibles, weighed, dried in oven overnight at $105^{\circ} \mathrm{C}$, and then placed in a mufflefurnace at $600{ }^{\circ} \mathrm{C}$ for $3 \mathrm{hrs}$. The loss in weight after ignition represents the crude fiber in the sample (AOAC 2005).

$\boldsymbol{\beta}$-Carotene: $\beta$ - Carotene content was determined using High Performance Liquid Chromatography (C-R6A, Shimadzu, Japan). Five grams of sample was saponified with 20 $\mathrm{ml}$ of $95 \%$ ethanol and $5 \mathrm{ml}$ of $100 \% \mathrm{KOH}$ and refluxed for $30 \mathrm{~min}$ at $85^{\circ} \mathrm{C}$. The mixture was extracted with hexane until the sample become colorless. The extracted sample was then filtered through a $0.45 \mu \mathrm{m}$. nylon membrane filter and analyzed using revised-phase high performance liquid chromatography .The test solution was injected under isocratic conditions into the $\mu$ Bondpack $\mathrm{C}_{18}$ column $(300 \mathrm{~nm} \mathrm{x}$ $3.9 \mathrm{~mm}, 125 \mathrm{~A}, 10 \mu \mathrm{m})$ with a ternary mixture of acetonitrile-methanol-ethyl acetate $(88: 10: 2$ $\mathrm{v} / \mathrm{v}$ ) as mobile phase with the flow rate of 1.0 $\mathrm{ml} /$ minute. Detection was performed at $436 \mathrm{~nm}$. The results expressed as $\mu \mathrm{g} / 100 \mathrm{~g}$ in dry weight (Tee and Lim 1991).

Preparation of Standard $\beta$-Carotene: Standard of $\beta$-Carotene solutions were prepared by taking $10 \mathrm{mg}$ in $100 \mathrm{ml} \mathrm{n}$-Hexane. The standard solutions were prepared as $20,40,60,80 \mathrm{ppm}$ dilutions.

Total phenolic content (TPC):Total phenolic content was determined according to the method described by Singleton et al., 1999 with some modifications.

Colour : Colour in terms of CIE $\mathrm{L}^{*}, \mathrm{a}^{*}, \mathrm{~b}^{*}$ values was measured with colour difference meter (Konica Minolta TR 400). In which $\mathrm{L}^{*}$ value represents lightness, a* value shows greenness-redness and $b^{*}$ value indicates blueness-yellowness, of the samples. The colour 
variation of cake mix during storage (90 days) and prepared product were evaluated.

Evaluation of microbial quality: The total plate count was conducted throughout the storage period to evaluate the microbial content of the products as described in AOAC (1990). One gram of test sample was taken and diluted in $9 \mathrm{ml}$ of distilled water. Added $1 \mathrm{ml}$ of this test sample to $9 \mathrm{ml}$ of diluents (water) using separate sterile pipets, prepare decimal dilutions up to $10^{-4}$. All plates were incubated at $35 \pm 0.5{ }^{\circ} \mathrm{C}$ for 48 hours.

Number of counts $(\mathrm{N})$ was taken per milliliter or per gram of product using the following equation.

$\mathrm{N}=\Sigma \mathrm{C} /\left(\mathrm{n}_{1}+0.1 \mathrm{n}_{2}\right) \mathrm{d}$

Where,

$\Sigma \mathrm{C}$ the sum of colonies counted on all the dishes retained.

$\mathrm{n}_{1}$ the number of dishes retained in the $1^{\text {st }}$ dilution

$\mathrm{n}_{2}$ the number of dishes retained in the second dilution; and

d the dilution factor corresponding to the first dilution

\section{Quality evaluation of prepared cakes}

Crude protein, moisture content, colour (internal cut surface) and external (outer appearance), total phenolic contents and $\beta$ carotene of the product were evaluated.

\section{Evaluation of organoleptic properties of prepared cakes:}

Three different recipes /formulas (Table. 01) were subjected to evaluate sensory properties. Thus, Prepared cakes were served for 15 trained panelists and evaluated for external appearance, internal appearance, colour, aroma, taste, texture and overall acceptability using 5 point Hedonic scale (5-like extremely, 4-like moderately, 3-neither like nor dislike,2-dislike moderately, 1-dislike extremely). The selected best formula was tested for physicochemical characteristics and its storability as dry instant cake mix.

\section{Statistical analysis}

Parametric data obtained from the study pertaining to the completely randomized design were analyzed using ANOVA SAS statistical package. Mean separation was done by using Least Significant Difference (LSD) at $\alpha=0.05$. The results with respect to sensory evaluation were analyzed using Friedman test of Minitab statistical package and treatment means were compared at $p<0.05$ using multiple comparison procedure.

\section{RESULTS AND DISCUSSION}

\section{Chemical analysis of ready to bake vegetarian cake mixes:}

The data obtained from the proximate analysis of three cake mixtures (treatments) are given in the Table 02. Slight increase in moisture content was observed in all treatments. Moisture contents of different cake mixes were in the range of 5.21-6.41\% and lowest moisture level was recorded by mixture (T3). The increase in moisture content might be due to hygroscopic nature of pumpkin powder and wheat flour and the higher water absorption capacity in the composite flour compared to wheat flour (Bhat and Bhat, 2013). Higher fat percentage was recorded in Mix-1 (T1) and Mix-3 (T3) and least $\%$ recorded in Mix 2 (T2). The reason may be due to incorporation of higher percentage of pumpkin flour in which high percentage of fat comparatively to wheat and rice flour. Higher percentage of protein was recorded in Mix 3 (T3) and Mix 2 (T2). Total ash content was ranged from 4.5-5.0\% and the higher fiber content $(2.5 \%)$ was recorded by Mix 2 (T2) and 
Mix 3(T3). The higher $\beta$ carotene content $(0.12$ $\mathrm{mg} / 100 \mathrm{~g}$ ) was recorded in Mix 3 and the lowest $(0.05 \mathrm{mg} / 100 \mathrm{~g})$ was recorded by mix 2 (T2). The higher $\beta$ carotene composition of Mix 3 (T3) may be due to addition of dehydrated bael powder together with dehydrated pumpkin flour affect to develop yellow color of the product.

Moisture, water activity, colour and total plate count of ready to bake vegetarian cake mixture with addition of different composition of pumpkin flour during storage is shown in Table03. The initial moisture content of cake mix 1,2 and 3 were $5.23 \%, 6.41 \%$ and $5.61 \%$ and it was increased up to $5.63 \%, 6.79 \%$ and $5.84 \%$ respectively. The moisture content was higher in Mix 1 and it was the lowest in Mix 3 (T3). The increase in moisture content due to hygroscopic nature of dehydrated fruit and vegetable powder, wheat flour and rice flour collectively and those substances were added in high proportions resulted in higher water absorption capacity in the composite flour mixes. The results were in conformation with Sunday and Dikson, 1992; Eke et al., 2009 in banana cake; See et al., 2007 in bread. Kulkarni and Joshi 2013 reported that the effect of replacement of refined wheat flour with pumpkin powder on the textural and sensory qualities of biscuit and the replacement level at $2.5 \%(\mathrm{w} / \mathrm{w})$ of refined wheat flour with pumpkin powder was found to be optimum for the preparation of carotene enriched biscuits. Microbiological quality is a common criterion used to determine the acceptability and shelf life of dehydrated plant based products. Microbial count of the dehydrated foods depends on handling quality during the period of processing and storage (Jay, 2000). There was no significant difference observed for water activity in 3 cake mixes beginning from initial storage period to 60 days and slight increase was recorded thereafter. The all three mixes tested were not exceeded the safe limit of water activity for all microorganisms $\left(0.6 \mathrm{a}_{\mathrm{w}}\right)$.Therefore lower microbial load were resulted. That may be due to maintenance of water activity below 0.62 in all samples during storage (Table 03). Addition of pumpkin flour proportionately increased the yellowness of flour mixes and the $\mathrm{L}^{*}, \mathrm{a}^{*}$ and $\mathrm{b}^{*}$ colour values were significantly $(p<0.05)$ higher in the mixes having higher percentage content of pumpkin powder. Mix 1(T1) recorded the lower $\mathrm{L}^{*}$ value (86.12) and the higher value (89.14) was recorded by Mix 3 (T3) at the end of storage. A reduction of colour intensity was observed due to destruction of $\beta$ carotene during storage.

\section{Evaluation of Organoleptic properties of prepared cakes:}

A sensory evaluation was conducted to determine the consumer acceptability aof the product and to select the best formula. Among the quality attributes evaluated, external appearance and taste were not shown any significant difference $(p<0.05)$ among treatments (Figure 01). All treatments tested were scored higher estimated median (5-Like extremely) for its external appearance. Mix $2\left(\mathrm{~T}_{2}\right)$ and Mix $3\left(\mathrm{~T}_{3}\right)$ given a highest score of estimated median (4-like moderately) for internal appearance, colour and aroma and it was significantly different from $\mathrm{T}_{1}$. Treatment three scored 4 (like moderately) in its all attributes which were tested and it was significantly different from other treatments. It was identified that the estimated median of overall acceptability in mix $1\left(\mathrm{~T}_{\mathrm{I}}\right)$ and Mix $2\left(\mathrm{~T}_{2}\right)$ were scored 2- dislike moderately and 3-neither like nor dislike respectively. Formula $3\left(\mathrm{~T}_{3}\right)$ was identified as a most preferable formulabased on sensory analysis. Findings are conformation with Pongjanta et al., 2006, reported that 20\% pumpkin flour incorporated butter cake and chiffon cake were scored higher estimated median values and it was significantly different from other treatment tested. The similar observations were recorded that Ravi et al., 2010, pupkin flour incorporated dhola mix had significant impact on chemical, physical and sensory properties. 
Table 02: Proximate composition of ready to bake vegetarian cake mix

\begin{tabular}{|c|c|c|c|}
\hline Composition & $\operatorname{Mix}-1(\mathrm{~T} 1)$ & $\operatorname{Mix}-2(\mathrm{~T} 2)$ & Mix-3(T3) \\
\hline Moisture (\%) & $5.61 \pm 0.01_{b}$ & $6.41 \pm 0.03$ & $5.21 \pm 0.01_{c}$ \\
\hline$(\%)$ & $1.8 \pm 0.02_{\mathrm{a}}$ & $1.4 \pm 0.02_{\mathrm{b}}$ & $1.8 \pm 0.02_{\mathrm{a}}$ \\
\hline Protein (\%) & $32.7 \pm 0.03_{\mathrm{c}}$ & $36.2 \pm 0.01_{\mathrm{b}}$ & $36.8 \pm 0.03_{\mathrm{a}}$ \\
\hline Total ash (\%) & $3.0 \pm 0.01_{c}$ & $3.4 \pm 0.01_{\mathrm{b}}$ & $4.5 \pm 0.01_{\mathrm{a}}$ \\
\hline Fiber $\quad(\%)$ & $2.4 \pm 0.01_{b}$ & $2.5 \pm 0.02_{\mathrm{a}}$ & $2.5 \pm 0.02_{\mathrm{a}}$ \\
\hline$\beta$ carotene $(\mathrm{mg} / 100 \mathrm{~g})$ & $0.07 \pm 0.02_{\mathrm{b}}$ & $0.05 \pm 0.03_{\mathrm{c}}$ & $0.12 \pm 0.01_{\mathrm{a}}$ \\
\hline
\end{tabular}

Means with the same letters on the same row are not significantly different at $\alpha=0.05$

Table 03: Physico- chemical and microbial analysis of ready to bake vegetarian cake mix during storage

\begin{tabular}{|c|c|c|c|c|}
\hline \multirow{2}{*}{ Parameter } & \multirow{2}{*}{ Days of storage } & \multicolumn{3}{|c|}{ Treatments } \\
\hline & & Mix 1 (T1) & $\operatorname{Mix} 2$ (T2) & $\operatorname{Mix} 3$ (T3) \\
\hline \multicolumn{5}{|l|}{ Moisture (\%) } \\
\hline & 0 & $5.61 \pm 0.02_{\mathrm{g}}$ & $6.41 \pm 0.01_{\mathrm{d}}$ & $5.21 \pm 0.02_{\mathrm{j}}$ \\
\hline & 30 & $5.62 \pm 0.01_{\mathrm{g}}$ & $6.47 \pm 0.03_{\mathrm{c}}$ & $5.30 \pm 0.01_{\mathrm{i}}$ \\
\hline & 60 & $5.73 \pm 0.02_{\mathrm{f}}$ & $6.63 \pm 0.03_{\mathrm{b}}$ & $5.47 \pm 0.02_{\mathrm{h}}$ \\
\hline & 90 & $5.84 \pm 0.01_{\mathrm{e}}$ & $6.79 \pm 0.01_{\mathrm{a}}$ & $5.63 \pm 0.01_{\mathrm{g}}$ \\
\hline \multicolumn{5}{|l|}{$a_{w}$} \\
\hline & 0 & $0.56 \pm 0.02_{\mathrm{e}}$ & $0.59 \pm 0.01_{\mathrm{b}}$ & $0.57 \pm 0.02_{\mathrm{d}}$ \\
\hline & 30 & $0.56 \pm 0.01_{\mathrm{h}}$ & $0.59 \pm 0.01_{b}$ & $0.57 \pm 0.01_{d}$ \\
\hline & 60 & $0.57 \pm 0.01_{d}$ & $0.59 \pm 0.02_{\mathrm{b}}$ & $0.58 \pm 0.01_{c}$ \\
\hline & 90 & $0.62 \pm 0.01_{\mathrm{a}}$ & $0.61 \pm 0.01_{\mathrm{a}}$ & $0.59 \pm 0.02_{\mathrm{b}}$ \\
\hline \multicolumn{5}{|l|}{ Colour } \\
\hline \multicolumn{5}{|l|}{$a^{*}$} \\
\hline & 0 & $2.94 \pm 0.01_{\mathrm{a}}$ & $2.56 \pm 0.02_{\mathrm{c}}$ & $2.88 \pm 0.02_{\mathrm{b}}$ \\
\hline & 30 & $1.85 \pm 0.01_{\mathrm{d}}$ & $1.66 \pm 0.02_{\mathrm{e}}$ & $1.56 \pm 0.03_{\mathrm{f}}$ \\
\hline & 60 & $0.61 \pm 0.03_{\mathrm{i}}$ & $0.56 \pm 0.03_{\mathrm{j}}$ & $0.75 \pm 0.01_{\mathrm{g}}$ \\
\hline & 90 & $0.68 \pm 0.02_{\mathrm{h}}$ & $0.51 \pm 0.01_{\mathrm{k}}$ & $0.75 \pm 0.01_{\mathrm{g}}$ \\
\hline \multicolumn{5}{|l|}{$\mathrm{b}^{*}$} \\
\hline & 0 & $16.70 \pm 0.03_{\mathrm{c}}$ & $16.76 \pm 0.03_{\mathrm{c}}$ & $16.89 \pm 0.02_{\mathrm{b}}$ \\
\hline & 30 & $16.45 \pm 0.02_{\mathrm{e}}$ & $14.64 \pm 0.02_{\mathrm{h}}$ & $16.54 \pm 0.01_{d}$ \\
\hline & 60 & $14.73 \pm 0.01_{\mathrm{g}}$ & $14.55 \pm 0.03_{\mathrm{i}}$ & $15.17 \pm 0.03_{\mathrm{f}}$ \\
\hline & 90 & $13.64 \pm 0.02_{\mathrm{k}}$ & $13.24 \pm 0.02_{\mathrm{i}}$ & $14.24 \pm 0.03_{\mathrm{j}}$ \\
\hline \multicolumn{5}{|l|}{$\mathrm{L}^{*}$} \\
\hline & 0 & $88.21 \pm 0.02_{\mathrm{k}}$ & $92.43 \pm 0.01_{\mathrm{a}}$ & $91.22 \pm 0.02_{\mathrm{e}}$ \\
\hline & 30 & $88.01 \pm 0.03_{\mathrm{i}}$ & $92.17 \pm 0.02_{\mathrm{b}}$ & $90.30 \pm 0.04_{\mathrm{f}}$ \\
\hline & 60 & $87.25 \pm 0.04_{\mathrm{m}}$ & $89.84 \pm 0.01_{\mathrm{g}}$ & $89.36 \pm 0.03_{\mathrm{i}}$ \\
\hline & 90 & $86.12 \pm 0.02_{n}$ & $88.25 \pm 0.02_{\mathrm{k}}$ & $89.14 \pm 0.03_{\mathrm{j}}$ \\
\hline \multicolumn{5}{|c|}{ Total plate count (CFU/g) } \\
\hline & 0 & $1.1 * 10^{3} \pm 0.02_{\mathrm{h}}$ & $5.3 * 10^{2} \pm 0.03_{\mathrm{i}}$ & $2.7 * 10^{2} \pm 0.03_{\mathrm{i}}$ \\
\hline & 30 & $2.0 * 10^{3} \pm 0.01_{\mathrm{de}}$ & $2.1 * 10^{4} \pm 0.03_{\mathrm{c}}$ & $1.4 * 10^{3} \pm 0.01_{\mathrm{gh}}$ \\
\hline & 60 & $1.7 * 10 \pm 0.01_{\text {ef }}$ & $2.3 * 10^{4} \pm 0.02_{\mathrm{b}}$ & $1.6^{*} 10^{3} \pm 0.01_{\mathrm{fg}}$ \\
\hline & 90 & $2.3 * 10^{3} \pm 0.01_{\mathrm{d}}$ & $2.4^{*} 10^{4} \pm 0.01_{\mathrm{a}}$ & $1.8 * 10^{3} \pm 0.02_{\text {ef }}$ \\
\hline
\end{tabular}

Means in each treatments followed by the same letter within each parameter are not significantly different alone the same columns and rows $\mathrm{p}<0.05$ 


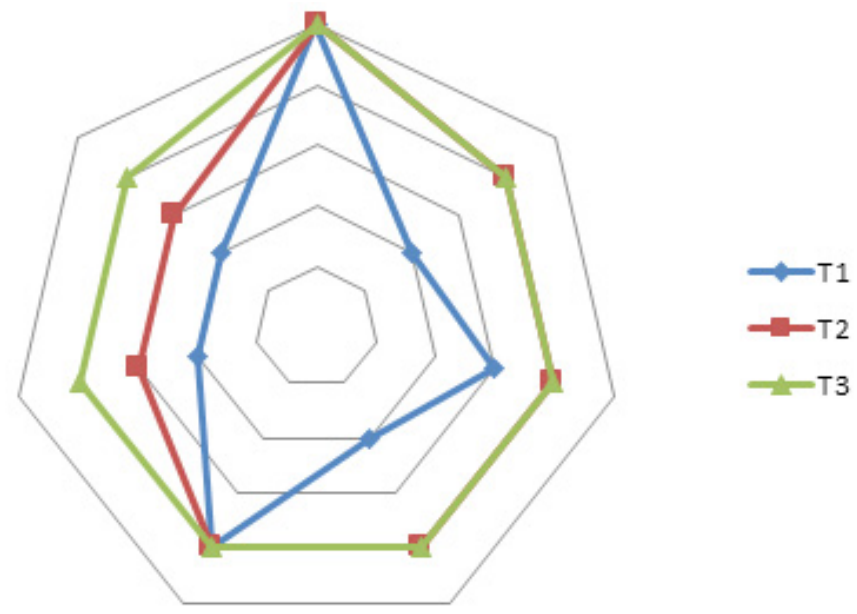

Hedonic scale: 5-Like extremely- Dislike extremely $(\mathrm{n}=15)$

\section{Figure.01: Sensory attributes of vegetarian cake}

Physico chemical properties of prepared cakes

The physicochemical properties of cake prepared by adding different treatments are given in Table. 04. Moisture contents of cakes were between $18.6 \%-22.30 \%$. The intensity of internal colour was increased while the percentage of pumpkin flour was increased and addition of dehydrated bael powder. Maximum $\mathrm{L}^{*}$ value is in mix 3 (50.69), and mix 1, (48.77). The $b$ value in mix 3 (41.24) followed by mix 1(39.41) respectively. According to the studies of Pongjanta et al., (2006) pumpkin flour incorporated butter cake, chiffon cake and sweet bread were reported that average $b^{*}$ values of all pumpkin powder substitute samples were higher than the control. However, water activity and texture was not significantly different $(p<0.05)$ for all levels of pumpkin flour substituted butter cake, chiffon cake and sweet bread. The protein content was $3.50 \%$ to $4.16 \%$ and higher protein content was recorded from the cake prepared by mix $3\left(\mathrm{~T}_{3}\right)$. Ravi et al., (2010) reported that incorporation of pumpkin flour in instant Dhokla mix resulted significant increase of nutrients such as protein, fiber and $\beta$ carotene.

Table 04: Physico chemical properties of vegetarian cake

\begin{tabular}{lccc}
\hline \multirow{2}{*}{ Parameter } & \multicolumn{3}{c}{ Treatments } \\
\cline { 2 - 4 } & Mix 1 (T1) & Mix 2 (T2) & Mix 3 (T3) \\
\hline Moisture \% & $18.6 \pm 0.02_{\mathrm{c}}$ & $22.3 \pm 1.32_{\mathrm{a}}$ & $19.51 \pm 1.46_{\mathrm{b}}$ \\
Colour (external) & & & \\
$\mathrm{a}^{*}$ & $11.59 \pm 0.02_{\mathrm{c}}$ & $10.58 \pm 0.12_{\mathrm{a}}$ & $10.90 \pm 1.23_{\mathrm{b}}$ \\
$\mathrm{b}^{*}$ & $14.4 \pm 0.01_{\mathrm{c}}$ & $10.26 \pm 0.02_{\mathrm{a}}$ & $12.26 \pm 1.37_{\mathrm{b}}$ \\
$\mathrm{L}^{*}$ & $32.24 \pm 0.02_{\mathrm{c}}$ & $24.90 \pm 1.34_{\mathrm{a}}$ & $31.68 \pm 1.01_{\mathrm{b}}$ \\
Colour (internal) & & & \\
$\mathrm{a}^{*}$ & $8.32 \pm 0.01_{\mathrm{a}}$ & $11.23 \pm 0.02_{\mathrm{c}}$ & $9.2 \pm 1.32_{\mathrm{b}}$ \\
$\mathrm{b}^{*}$ & $37.61 \pm 1.32_{\mathrm{a}}$ & $39.41 \pm 1.12_{\mathrm{b}}$ & $41.24 \pm 0.12_{\mathrm{c}}$ \\
$\mathrm{L}^{*}$ & $46.18 \pm 0.23_{\mathrm{a}}$ & $48.77 \pm 0.12_{\mathrm{b}}$ & $50.69 \pm 0.22_{\mathrm{c}}$ \\
Protein $(\%)$ & $4.08 \pm 0.12_{\mathrm{a}}$ & $3.50 \pm 1.32_{\mathrm{b}}$ & $4.16 \pm 1.46_{\mathrm{c}}$ \\
$\beta$ carotene (mg/100g) & $0.03 \pm 0.21_{\mathrm{b}}$ & $0.02 \pm 0.27_{\mathrm{c}}$ & $0.07 \pm 0.13_{\mathrm{a}}$ \\
Total phenolic content (mgGA/g) & $3.05 \pm 0.24_{\mathrm{c}}$ & $3.21 \pm 1.23_{\mathrm{b}}$ & $3.40 \pm 0.11_{\mathrm{a}}$ \\
\hline
\end{tabular}

Means in each treatments respect to different parameters followed by the same letter alone the columns were not significantly different at $\mathrm{p}<0.05$ 


\section{CONCLUSIONS}

In conclusion, cake mixture $T_{3}$ was the $(17 \%)$, bael powder $(3 \%)$ and pumpkin flour best formula as a vegetarian cake mix. The (15\%).

\section{REFERENCES}

Ahamed, K.U., Akhter, B., Islam, M.R., Ara, N. and Humauan M.R. (2011). An assessment of morphology and yield characteristics of pumpkin (Cucurbita moschata) genotypes in northern Bangladesh. Tropical Agriculture Research and Extension 14(1):7-11.

AOAC. (1990). Official Methods of Analysis. Vol.2. Association of Official Analytical Chemist, Inc., Verginia 69-81pp

AOAC. (2005). Official methods of analysis, $18^{\text {th }}$ edn. Association of Official; Analytical Chemists, Washington DC.

Bhat A.M. and Bath A. (2013). Study on physicochemical characteristics of pumkin blended cake. Food Processing and Technology.4(9):1-4

Boileau, T.W.M., Moore, A.C. and Erdnman, J.W. (1999) Carotenoid and vitamin A. Antioxident status, diet, nutrition and health ( eds. A.M. Papas). pp 133-138. CRC Press, Florida, USA.

Chakravarty, I. (2000) .Food based strategies to control vitamin A deficiency. Food and Nutrition Bulletin. 21:135-143.

Eke, J. Sanni, S.A. and Owuno, F. (2009) Proximate and sensory properties on banana cake. Nigerian Food Journal 27:102-106.

Jay, J.M. (2000). Preservation of foods by drying, In: Modern Food Microbiology. $6^{\text {th }}$ Edition. An Aspen Publication, Aspen Publishers, Inc, Gaithersburg, Maryland. pp. 363-374.

Kulkarni, A.S. \& Joshi D.C. (2013) Effect of wheat flour with pumpkin powder on textural and sensory qualities of biscuit. International food Research Journal 20(2): 587-591

Nisha, S.K. and Veerarangavathatham, D. (2014). Heterosis and combining ability for fruit yield and its component traits in pumpkin (Cucurbita moschata Duch. ex Poir.). Advancec in Applied Research 6(1): 158-162.

Pongjanta, P., Naulbunrang A., Kawngdang S., Manon T. and Thepjaikat, T. (2006).Utilization of pumpking powderin bacary products. Songklanakarin Journal of Science and Technoogy. 28(1):71-79.

Ptitchkina, N.M., Novokreschonova, L.V., Piskunova G.V. and Morris, E.R. (1998). Large enhancements in loaf volume and organoleptic acceptability of wheat bread by small additions of pumpkinpowder: possible role of acetylated pectin in stabilizing the cell structure. Food Hydrocolloid 12:333-337

Ravi, U., Menon, L. and Anupama, M. (2010). Formulation and quality assessment of instant dhoka mix with incorporation of pumpkin flour. J. Sci. Ind. Res 69:956-960 
See, S.F., Wan, N.W.A. and Noor, A.A.A. (2007). Physicochemical and sensory evaluation of breads supplemented with pumpkin flour. Asian Food Journal 14:123-130

Singleton, V.L. and Lamuela-Raventos, R.M. (1999). Analysis of total phenols and other oxidation substrates and antioxidants by means of Folin-Ciocaltue regent: Enzymeol. 299: 152-178.

Sunday, Y.G. and Dikson, A.B. (1992). Proximate composition and functional properties of raw and process full-fat fluted pumpkin (Talfairia occidentalis) seed. flour. Journal of the Science of Food and Agriculture 59:321-325.

Tee, E.S. and Lim, C.L. (1991) Carotenoid composition and content of Malaysian vegetables and fruits by the AOAC and HPLC methods. Food Chemestry 41:309-339.

Usha, R., Lakshmi, M. and Ranjani, M. (2010). Nutritional, Sensory and Physical Analysis of Pumkin flour Incorperated Weaning Mix. Malaysian Journal of nutrition 16(3):379-387.

Vidanapathirana, R.P. (2008). Marketing margins of the domestic vegetable trade in Sri Lanka. Sri Lanka Journal of Agrarian Studies 12 (2): 36 - 60. 